\title{
The Identification of the Luhansk Region and the Region Act's According to the Qualification of Their Sustainable Development in the Conditions of the Joint Forces Operation
}

\author{
Identyfikacja regionu Ługańska i regionalnego prawa \\ zgodnie z wymaganiami zrównoważonego rozwoju \\ w warunkach Operacji Wspólnych Sił
}

\author{
Inna Zablodska, Svitlana Hrechana*, Daria Zablodska \\ National Academy of Sciences of Ukraine, Department of Interregional \\ Cooperation Problems, Institute of Economic and Legal Research, \\ Str. Marii Kapnist 2, 323, Kyiv, Ukraine, 03057 \\ E-mail (corresponding author):*svigrech@gmail.com
}

\begin{abstract}
Each region has its own set of unique characteristics, which should create the basis for their growth and give residents a sense of home and safety. This article develops an approach to identifying a region and its amalgamated territorial communities in order to identify their strengths and values, based on the example of Luhansk region, which, due to ongoing military aggression, has significant development problems. It is proposed to quantify the results of complementary analysis of sustainable development indicators by quantitatively qualitative transformation of such indicators and rating points into a gradient of territorial features, which is visualized using the quantification axis to determine the unique characteristics of region. The application of such methodology for identifying a region greatly simplifies the process of identifying the benefits and values of a region in order to properly position and build an effective socio-economic development strategy.
\end{abstract}

Key words: identification, region, amalgamated territorial communities, sustainable development, quantification, Joint Forces Operation

\begin{abstract}
Streszczenie
Każdy region ma swój własny zestaw unikalnych cech, które powinny stanowić podstawę rozwoju i dać mieszkańcom poczucie przebywania we własnym domu i bezpieczeństwa. W tym artykule opracowano temat identyfikacji regionu i jego połączonych społeczności terytorialnych w celu określenia ich mocnych stron i wartości, na podstawie regionu Ługańska, który z powodu trwającej agresji wojskowej cierpi na poważne problemy rozwojowe. Proponuje się kwantyfikację wyników uzupełniającej analizy wskaźników zrównoważonego rozwoju poprzez ilościowo-jakościową transformację takich wskaźników i punktów oceny w gradient cech terytorialnych, który jest wizualizowany za pomocą osi kwantyfikacji, w celu określenia unikalnych cech regionu. Zastosowanie takiej metodologii do identyfikacji regionu znacznie upraszcza proces identyfikacji korzyści i wartości regionu w celu właściwego pozycjonowania i zbudowania skutecznej strategii rozwoju społecznogospodarczego.
\end{abstract}

Słowa kluczowe: identyfikacja, region, połączone społeczności terytorialne, zrównoważony rozwój, ujęcie ilościowe, Operacja Wspólnych Sił 


\section{Introduction}

Today, one of the main priorities of the Ukrainian state policy is sustainable regional development, within which the appropriate conditions for the dynamic, balanced socio-economic development of territories were formed, including through the reformation of administrative-territorial structure. The regions and amalgamated territorial communities (ATC) during the decentralization reforms are putting forward their strategies for persistent, sustainable development and trying to implement them in an effort to improve economic, economic and environmental concerns and any issues. Such approach and active government support has been provided by some positive results as their own ATC subsidiary budgets by expanding their infrastructures, extending available residents to administrative, medical, utilized and other public services. However, along with their overall success, they are addressing broad-based decentralization, which is the accidental inhibition of territorial development, which remains unremarkable in practice, and local authorities and local governments are reaping the benefits. Additionally known destabilizing reconciliations can be permanent site, neglected production, transport and information infrastructure, lack of significant resources, insufficiently reliable apparatus management specialists, and important party capabilities.

Since 2014, the main destructive factor for the sustainable development of the country and regions is the annexation of Crimea and external military aggression in the east of Ukraine. According to the $\mathrm{UN}$, this military conflict is one of the deadliest in Europe since World War II: in the five years of the war, 13,000 people were killed, 28,000 wounded, and about 1.8 million people in the Donbas and Crimea became internally displaced. Occupied 17 thousand km 2 of Donetsk and Luhansk regions, which together with Crimea makes up $7.2 \%$ of the territory of Ukraine. $409.7 \mathrm{~km}$ of the UkrainianRussian border remain uncontrolled (Ukrinform, 2019). The negative impact of aggression was felt by the whole country; however, the most affected regions were Luhansk and Donetsk regions. The military operations are still taking place, and the Joint Forces Operation (JFO) was launched (until 2018 - Anti-Terrorist Operation (ATO) - a complex of military and special legal measures of Ukrainian law enforcement agencies aimed at counteracting the activities of illegal Russian and proRussian armed forces in the war in eastern Ukraine. Luhansk region is located in the southeastern part of Ukraine. The favorable geographical position at the crossroads of major transit routes between the countries of Europe and the Caucasus, as well as the rich raw material base, have caused the industrial development of region in the last century. However, a considerable part of this property was lost during the armed conflict (about $50 \%$ of Donbas industrial potential: 388 state-owned enterprises, 4,500 state-owned property (real estate) and over 100 large non-state-owned enterprises remained in the occupied territories (Razumkov Centre, 2019). As a result, the region transformed from an industrial to an agrarian. Due to the forced migration of a considerable number of internally displaced persons from the occupied territories, the load on the already backward infrastructure increased. Thus, according to the estimates of experts from the European Union, the United Nations and the World Bank Group, as of the beginning of 2015 , the total needs for reconstruction of infrastructure and social services in Ukraine were estimated at 1.26 billion USA (UNDP, 2018). A very difficult situation is also in the ecological sphere, which is complicated by the location of major air pollutants and water resources in the territories not controlled by the Ukrainian authorities.

However, despite the borderline between the military conflict and the Joint Forces Operation area, the sustainable development of Luhansk region and its amalgamated territorial communities is a vital condition. Achieving its goals in such an aggressive exo environment requires not only the joint efforts of legislative levels and executive power but also the cohesion of civil society. Along the way, the Luhansk region has made a huge breakthrough by introducing the decentralization reform, forming in the communities the desire of people for change their living environment, awareness of their enormous responsibility. That is why the identification of region and the communities in the process of permanent confirmation of their own financial capacity and competitiveness against other administrative and territorial entities is an urgent need. Today, they are identified only by their names, they positioned as being close to the conflict zone, which reflects neither the values nor advantages of Luhansk region and ATC's, which has rich potential for development and cooperation. That is why it is appropriate to identify the unique characteristics inherent in the region and it ATC's, as being in the Joint Forces Operation area creates an urgent need for repositioning them for further effective development.

\section{The conceptual approaches and research methodology}

Each region has its own authenticity and uniqueness, each locality being something different from thousands of others, identifying it with the totality of values that unites the territory. In the general sense, the term identification means the process of conscious (emotionally conscious) identification of a community with a group or ideal, assimilation of the norms, values, standards of behaviour of such communities to which the community belongs or 
seeks to belong (Sabatier \& Jenkins-Smith, 1993; Murdoch, 2000; Csurgó \& Szatmári, 2019). In this context, the process of identification is a function of self-determination and the conscious or unconscious acquisition of an object of self-identity. The successful result of such a process is the formation of territorial (regional, urban, local) identity.

The general concept of identity that defines a person as a person within society is present in the discourse of politicians, practitioners and researchers with a wide variety of scientific fields. However, different sciences, interpreting identity and the process of identification, place different critical content and place different emphasis, ensuring that there is no single agreed position on the essence of these concepts. In addition, if today in the scientific literature sufficiently substantively presented studies of gender (cognitive), political, religious, cultural, historical (collective memory) identity, etc., in the field of territorial and spatial identification of such works is not enough.

An identity is an internal positional designation that represents the meanings actors use to define themselves as unique individuals (person identities), role occupants (role identities) or group members (social identities) (Stets 2006; Stryker [1980] 2002). It is a generalized definition given by identity theory as a social psychology research program (Burke \& Stets, 2009). Both sociology and psychology base the understanding of identity on the fact that it not only affects the self-esteem of individual, but also in many respects provides it. Quite a number of papers describe the interplay of identity and personality behaviour in different hierarchies and social settings (Stryker, 1980; Felson, 1985; Hogg \& Abrams, 1988; Burke, 1991; Stets \& Burke, 2005; Aquino et al., 2007; Stets \& Carter 2006, 2011).

In contrast to this emphasis, the identity of a territory (country, region, city, community, etc.) usually is considered in relation to the historical heritage and traditional features of the region (Deffner \& Metaxas, 2007). The concepts of territorial spatial identities emphasize the recognition by one or another territorial community of such shared values that are not only recognized as 'theirs' but also capable of forming a solid basis for consolidation (Nahorna, 2008). However, in this area of research, there is no more or less unified definition of essence of this concept. Objectively, this is due to the variety of scales that the study area may occupy, so the scientific literature addresses two main groups of territorial spatial identities: national and regional (territorial, urban, local).

National identity is inseparable from the concepts such as nation and nationalism, which are rooted in common history and are particularly strong in terms of group social identity (Shao \& Lange \& Thwaites, 2017). The territorial-spatial or territorial identity is the perception of individual as a representative of a certain imagined community, which is based on the unity of the territory residence, history and traditions, socio-cultural experience, values and lifestyle (Korzhov, 2010). Urban identity is proposed to be defined as the physical and social characteristics of a place that characterize the perceived uniqueness of their residents and observers (tourists) (Bernardo \& Almeida \& Martins, 2016). Such an identity, which on the one hand is quite stable but on the other is constantly changing, is a significant factor in urban development and is an important aspect of it (Oktay, 2002). Local identity is a strong, independent image of a small-scale territory, such as a settlement, small community, city block, or street, which distinguishes this place and the residents themselves from other similar places and provides residents with a sense of peace, security and pride as they live in this place (Shao \& Lange \& Thwaites, 2017).

Thus, at all levels, people identify themselves with a certain scale of territory with its inhabitants, culture, traditions, landscape, etc. That is why a great number of researchers consider the essence of territory's identity with respect to its historical heritage, cultural and behavioral traditions and unique social characteristics, emphasizing that regional (urban, local). Identity should provide a basis for the development of a region (city, community) while preserving local traditions in a rapidly changing environment, and develop a sense of home and safety for the locals. That is, it becomes a subject of research in the context of socio-economic development of region and the administrative and territorial units, as it concerns the quality and nature of human relations and the stability of social capital that affect their sustainable development.

The purpose of this article is to formulate an approach to the identification of Luhansk region and its amalgamated territorial communities, which carry out their activities under the conditions of Joint Forces Operation and proximity to military actions. In order to determine their advantages and values, the totality of which will be useful for making appropriate adjustments to the local socioeconomic development strategies and plans for their implementation.

In the current scientific literature, a sufficiently unified procedure for carrying out territorial and spatial identification is not formulated. Pritchard and Morgan have proposed such authentication through a combination of regional historical, social, economic and political processes (Pritchard \& Morgan, 2001). Raszkowski substantiates the need to study the level of territorial identity in the context of its impact overall spectrum of phenomena that have a direct or indirect impact on the process of local development (Raszkowski, 2014). However, most researchers agree that the territorial spatial identification should result in a set of values, preferences, and characteristics of a region, city, or 
community that, typically, cannot be measured quantitatively but require qualitative research (Gerencsér, 2019), approximating this process to an empirical assessment of the development success of concerned locality or territory. This approach correlates with the methodological way of research work performing of Luhansk Branch of the Institute of Economic and Legal Research of the National Academy of Sciences of Ukraine on the theme Identification and positioning of amalgamated territorial communities in the east of Ukraine (Ustymenko et al., 2019), which is an intermediate result of implementation this article. Therefore, the approach to determine a local territorial identification used in the study is based on the method of quantifying the results of complementary analysis of sustainable development indicators of region and it ATC's in the context of identifying the main features of attractiveness to investors, residents, business entities, qualified personnel. That is, the qualitative judgments about the state, dynamics and problems of the region's development by each component - economic, social, environmental, which represent a large set of information, were grouped and ordered by the total estimates of the territories strong features. Such quantitative and qualitative transformation of data allows not only to isolate but also to graduate regional features. The quantification of sustainable development results formulated in this paper formalizes and visualizes the result of the applied methodology, which simplifies the process of identifying the advantages and values of Luhansk region for its proper positioning and creation of an effective socio-economic development strategy.

\section{The sustainable development of Luhansk re- gion in the context of territorial-spatial identity}

Before the external aggression in 2014, the Luhansk Oblast, which occupied $4.4 \%$ of the country's total area, was one of the five most powerful industrial and economic regions of Ukraine, having a strong multi-sectoral industry (mainly coal, chemical and metallurgy), a developed transport network, communications, high population density and considerable intellectual potential. It has given it an undeniable advantage over other regions of country. After five years of war, only $69 \%$ of the territory (35 administrative and territorial units of the region, including 12 districts of 18,15 cities of 37), with 684.1 thousand people, and 280, 5 thousand are registered as internally displaced persons (Luhansk Regional State Administration, 2019). The greatest damage was done to the industrial sites, more than $80 \%$ of which remained in the occupied territory, transport and energy infrastructure, business logistics, therefore the role of areas of northern part of the region - as agricultural production zones increased.
Due to the armed aggression and the Joint Forces Operation, the number of factors hindering the balanced regional development of the region, especially in the fields of industrial production, transportation, energy supply, has also increased. They are caused not only by a direct damage from fighting in the region (deaths and injuries of people, loss of part of territories, enterprises, infrastructural objects, damage and destruction of state and private property), but also by the failure of local self-government bodies to delegate them for a long time. The increase in the number of IDPs has led to an excessive social and administrative burden on public authorities, local governments, communities, local labor markets, and the social infrastructure of the region. In some cities and districts, the number of IDPs equals or even exceeds the population of these territories. Only $68 \%$ of the territories and settlements of the area under the control of the Government of Ukraine are provided with town planning documentation, much of which has lost its relevance and needs to be updated or modified. Sievierodonetsk is the city of regional significance, where the Luhansk regional state administration is the regional military-civil administration and other institutions of state regional power was transferred, has not officially received the functions of the regional center, which causes a significant conflict in the distribution of local self-government bodies' powers. Due to the frequent change of region leadership, the region does not have a single clear socio-economic policy, despite the adoption of Luhansk Region Development Strategy until 2025, which exacerbates tensions at various points of influence. In 6 amalgamated territorial communities (out of 23 established in the region as of 01.07.2019), the local elections are still not called due to the inability to observe the security of electoral process in the immediate vicinity of demarcation line or the location of one of newly formed communities settlements in the occupied territory. All these could not be affected the indicators of sustainable development of the region. According to the results of socio-economic development monitoring of regions, which is conducted annually by the Ministry of Regional Development, Construction and Housing and Communal Services of Ukraine, Luhansk region is in the last place in the ranking of 25 regions (Fig. 1).

Such a result, as well as the penultimate place of Donetsk region, which is also in the zone of military conflict, was repeated year after year after the beginning of aggression (Ministry for Regional Development, Construction, Housing and Communal Services of Ukraine, 2016-2018). Such a logical result of comparing the indicators of conflict territories development with peaceful gives, on the one hand, an understanding of the depth of the harm done to the affected regions, and on the other, sets out appropriate growth benchmarks. 


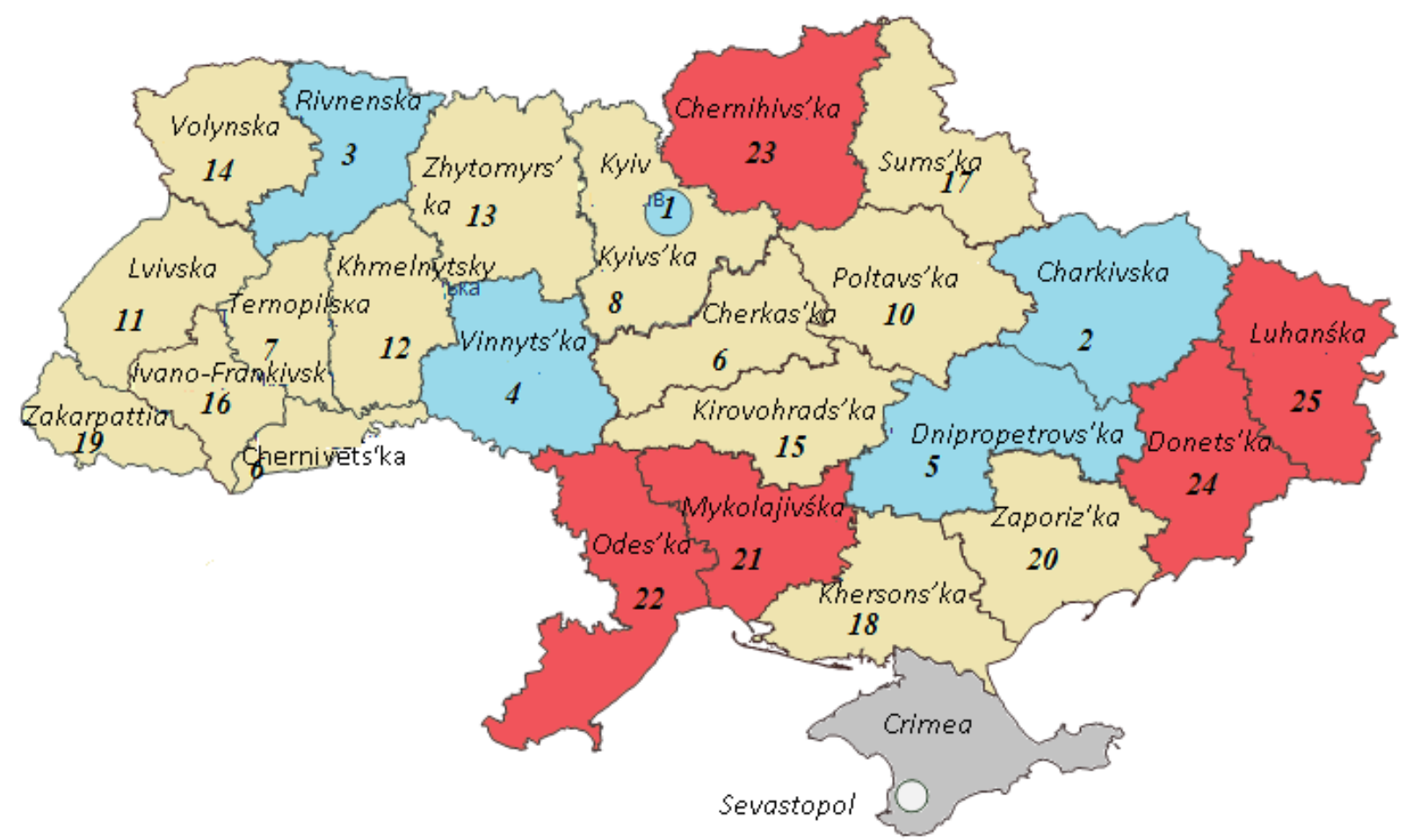

Figure 1. Rating of Ukraine's regions according to the results of monitoring their socio-economic development in 2018 (Ministry for Communities and Territories Development of Ukraine, 2019)

Table 1. Selected indicators of economic development of Luhansk region, built by authors according to (Statistical publication Regions of Ukraine, 2018; State Statistics Service of Ukraine, 2019)

\begin{tabular}{|l|c|c|c|c|c|}
\hline \multicolumn{1}{|c|}{ Indexes } & 2014 & 2015 & 2016 & 2017 & 2018 \\
\hline Gross regional product, mln.UAH & 31393 & 23849 & 31356 & 30285 & - \\
\hline Volume of industrial production (goods, services), mln. UAH & 39400,7 & 23865,6 & 37697,8 & 24472,9 & 22846,6 \\
\hline Industrial production index & 58,0 & 34,0 & 139,0 & 69,0 & 83,0 \\
\hline Agricultural production volume index, \% & 79,8 & 77,8 & 119,3 & 94,0 & 103,5 \\
\hline Construction products index, $\%$ & 46,7 & 49,2 & 118,1 & 74,2 & 87,1 \\
\hline Capital investment index, $\%$ & 39,2 & 26,1 & 146,4 & 102,2 & 91,6 \\
\hline Foreign Direct Investment Index, \% & 70,0 & 76,8 & 98,3 & 101,2 & 99,7 \\
\hline Total exports of goods, mln. USA & 1902,6 & 257,8 & 435,7 & 233,9 & 202,9 \\
\hline Total imports of goods, mln. USA & 1017,2 & 318,4 & 357,4 & 273,2 & 285,0 \\
\hline Financial results of enterprises before tax, billion UAH & $-46,6$ & $-51,5$ & $-25,2$ & $-25,8$ & 2,1 \\
\hline Number of economic entities, approx. & 24425 & 21320 & 21589 & 21296 & 21849 \\
\hline
\end{tabular}

However, the comparison of any ratings does not give clear results, since there is always a disproportionate regional development and the regions are influenced by various external factors, including insurmountable force. Similarly, comparing data on the socio-economic status of Luhansk region before and after the outbreak of the armed conflict gives a much-distorted estimate due to a significant change in area, population, industrial potential, infrastructure, etc., requiring appropriate adjustments. That is why the results of socio-economic development rating of the regions of Ukraine, which are very informative, but need to be expanded. This addition is a qualitative assessment of indicators dynamics that characterize the changes in economic, social and environmental spheres. The multiplication of such assessments provides a clear picture of the region's current state undergoing prolonged armed conflict and provides a basis for identifying opportunities for its sustainable development and for the formation of territorial and spatial identity.

\subsection{Demographic situation in the Luhansk region}

The current demographic situation in the Luhansk region is characterized by unfavourable trends and negative shifts in the population structure, which corresponds to the national Ukrainian trend. The number of population in the controlled territory of region is actively decreasing from 715.2 thousand people (as of 01.01.2016) up to 684.1 thousand people (as of 01.01.2019) and is aging (in 2014 the average age of the population was 42.4 years, in $2019-45,8)$. However, the dynamics of both indicators are gradually diminishing. In 2018, the percentage of economically active population in the Luhansk region is the highest in the previous four years $(67.7 \%$ in $2014,64.7 \%$ in $2015,66.2 \%$ in 2016 , and $65.6 \%$ in 2017). However, most of eco- 
nomically active population is not accounted. They receives no official income, that is, the persons employed illegally and migrant workers. This has a negative impact on the employment rate, which though increased compared to 2014 (56.9\% versus $52 \%$ ), but had divergent dynamics. The unemployment rate in the region during 2014-2018 also increased by almost 4 percentage points, accounting for $15.1 \%$ in 2018 . This is mainly due to the production problems at the enterprises in the context of ongoing-armed conflict and the preservation of significant risks for investors in financing the reconstruction and ensuring the stable operation of large enterprises. The same factors have a negative impact on the level of wages in the region, which has increased more than twice in four years (from UAH 3,377 in 2014 to UAH 7,365 in 2018), but its growth rates are slowing down from 2017 (in 2016) $35.31 \%$ in $2017,26.42 \%$ in $2017,25.64 \%$ in 2018 ). However, because of the resumption of state control over employment, legalization and more comprehensive and innovative approach to staffing employment services and other government agencies, in 2018 , the employment rate has started to rise slightly and the unemployment rate has decreased. An analysis of labour market demand and supply shows that demand for labour in the region is increasing. At the same time, the demand for skilled workers is growing at a relatively high rate. Most of the vacancies are found in agricultural enterprises (41.2\%), public administration and defense $(11.0 \%)$, as well as in trade and repair $(9.8 \%)$. By occupational groups: equipment and machinery maintenance workers are in the highest demand of employers $(36.2 \%)$, representatives of the simplest professions (16.7\%), skilled workers (11.9\%) (Statistical publication Regions of Ukraine, 2018; State Statistics Service of Ukraine, 2019).

\subsection{Dynamics of regional economy development} The situation in the economic sphere of the Luhansk region is even more controversial (Table $1)$.

Until 2014, in the structure of national economy, the Luhansk region was one of the largest in terms of potential, major economic indicators corresponded to the average national level in Ukraine (Semenenko \& Halhash \& Sieriebriak, 2019). To date, the region has shifted from 10th place to 24th place in gross regional product indicator, from 15 th place to 24th place in gross regional product. An additional limiting factor for economic development was the temporary suspension in 2017 of the movement of goods through the line of collision with railways and motorways within the region, which led to the shutdown of enterprises and disruption of production activities in certain sectors of economy, at first in industry that has been negatively developing for almost all years. In the area controlled by the Ukrainian authorities, the industrial complex actually lost such industries as metallurgy, coke and oil refining, and mechanical engineering; partly coal industry, production of building materials, food and light industry. Leading companies in the chemical, paper, printing, gas (gas distribution) and electricity (Luhansk Regional State Administration, 2019) industries are almost completely left. The main industrial enterprises are concentrated in the cities of Sievierodonetsk, Rubizhne, Lysychansk and Kreminna, which form about half of the industrial production of region.

Due to the temporary occupation of a part of Luhansk region, which accounted for about $70 \%$ of the region's industrial potential, the region became agrarian region. Today, the agro-industrial complex provides about $20 \%$ of gross value added and is one of the main budgetary sectors of economy. At the same time, in the structure of gross production of region the crop occupies $86.1 \%$, animal husbandry - $13.9 \%$ (Luhansk Regional State Administration, 2019). Despite the increase in agricultural output indices, the industry has a sufficient number of problems associated with the complete or partial loss of manufacturing facilities, the loss of major domestic markets, the destruction of logistics, the rupture of production links between agricultural producers and enterprises with its agricultural producers processing. Of course, the agricultural sector of the region will not replace the industrial complex equally, but it can solve some of regional problems, in particular due to the development of the processing industry. Thus, the economy of Luhansk region, which had a low level of diversification, is approaching a medium-diversified level in view of the decreasing share of industry and development of other industries.

Military action in the region has led to the destruction of a significant number of residential and nonresidential buildings, engineering structures, and a significant decrease in fixed capital investment and a critical decline in construction activity, as evidenced by changes in the index of production in this industry. The volume of construction products produced in the 2014-2018 period decreased by almost a quarter, reaching UAH 635.8 million in 2018 (State Statistics Service of Ukraine, 2019). In this case, new construction is hardly done - the main work in this area is aimed at repairing and repairing damaged objects. Despite this, the construction industry is considered extremely promising for the region, not only for the reconstruction of critical infrastructure, but also for the construction of new facilities, including housing for internally displaced persons.

The volume of capital investments in 2017-2018 in the region stabilized somewhat at the level of UAH 3 billion per year; however, it is only $61 \%$ of the 2014 level. At the same time, capital investment in agriculture increased to UAH 1.2 billion in 2018 (against UAH 0.2 billion in 2014) amid a fall in 
capital investment in industry - UAH 0.7 billion in 2018 (against UAH 4.4 billion in 2014). The main source of capital financing investments are the own funds of enterprises and organizations, at the expense of which approximately $60 \%$ of the total volume is spent, $40 \%$ - at the expense of the state and local budgets. Unfortunately, only $51.4 \%$ of enterprises in the region are profitable (by 2018, this figure was at the level of 76-79\%), which for the first time during the war has provided a positive financial result of the region, whose level is, unfortunately, insufficient for investment growth (State Statistics Service of Ukraine, 2019).

The volume of foreign investments in the region stabilized somewhat at 0.4 billion USA for the year 2017-2018, but this is only $65 \%$ of the 2014 level. The main reasons are the complication of the technological and production process, the emergence of logistical problems (the overwhelming share of foreign investments involved in industry), the international armed conflict in the region, the loss of markets in the temporarily occupied territory of the Luhansk region (State Statistics Service of Ukraine, 2019).

Compared to 2014, the exports of goods decreased by more than 9 and imports - by 3.5 times. Due to temporary suspension of goods movement through the collision line, the volume of goods exports of the metallurgical industry was significantly reduced, the main exporter of which was PJSC Alchevsk Metallurgical Works. Against this background, and an increase in the share of agriculture exports, a geographical redistribution of the region's exports occurred: the share of EU countries decreased from $50.4 \%$ in 2017 to $36.5 \%$ in 2018 , where ferrous metallurgy was supplied, and the share of Asian countries where it occurs supply of agricultural products.

In the structure of economic entities of Luhansk region, the number of which decreased by $10.5 \%$ in four years, is dominated by small and mediumsized businesses (SMEs). As of January 1, 2019, there are only six large enterprises in the controlled territory of the region. The share of products sold by SMEs in the regional sales of products annually increases from $41.9 \%$ in 2014 to $69.7 \%$ in 2018 . Unlike large enterprises, there is a sharp decline in all key indicators (production volumes, number of employees) and employees) in the SME sector is undergoing a gradual improvement (Luhansk Regional State Administration, 2019; State Statistics Service of Ukraine, 2019).

Such negative tendencies of economic development of the region could not affect the filling of budget revenues. Today, the Luhansk region is the only one in Ukraine with a budget deficit. However, there is a gradual increase in local budget revenues from UAH 7.4 billion in 2014 to UAH 8.8 billion in 2018. At the same time, there is a tendency to increase the volume of official state transfers for expenditures of local budgets, the main part of which goes to the social sphere. The region's own revenues in 2018 reached the level of 2014 (UAH 3 billion) and make up $34 \%$ of the total income. The main source of own income is the personal income tax (about $70 \%$ of the total amount of own income). It is worth noting a slight but steady increase in the share of the single tax (from $7 \%$ to $12 \%$ ) in the budget revenues in 2014-2018, which is a direct evidence of small and medium-sized businesses development in the region. In the structure of the region's budget expenditures, traditionally, the leadership is in the social spheres - education $(30.7 \%)$, health care $(21.4 \%)$ and social protection $(25.1 \%)$. Construction and regional development are far behind in terms of costs - only $3 \%$. There is a significant increase for revenues to the development budget of the region from UAH 161.6 million in 2014 to UAH 1012.2 million in 2018. At the same time, these funds accumulate at the regional level $-75.5 \%$, cities and ATC - 24.5\% (Regional State Administration, 2019).

\subsection{Social sphere and access to social services}

As a result of armed aggression and active fighting in the Luhansk region, the situation in the social sphere has significantly worsened: decrease in the standard of living and a decrease in access to quality social services (reduction of the number of educational, health, social protection, etc.). Thus, the disposable income per capita in the region over the four years increased by only $4.2 \%$, from 19788.3 UAH in 2014 to 20618,6 UAH in 2018, while in Ukraine, on average, such growth exceeded twice (from UAH 26782.1 to UAH 57908.6) (Statistical publication Regions of Ukraine, 2018; State Statistics Service of Ukraine, 2019). In addition, in 20152016 there was a decline in the already not the best level of income, although the Ukrainian trend was the opposite.

In addition, the territory under the control of Ukraine underwent a significant reduction in the network of educational institutions. Since 2014, the number of pre-school educational institutions has decreased by $58 \%$, of schools - by $56 \%$. In 2018 , their numbers continue to decline to 250 (against 598 in 2013) and 279 units (against 690 in 2013), respectively. The average occupancy of general secondary education institutions is $44.8 \%$, and the number of students per teacher is nine. The professional (vocational) education has undergone significant changes. In 2014, there were 27 institutions of vocational (vocational-technical) education in the territory controlled by the Ukrainian authorities (up from 78 in 2013). Accordingly, there have been changes in student admission volumes. Thus, in 2018, the number of people enrolled for training was 2.4 thousand, or $66.7 \%$ compared to 2014 . The number of higher education institutions has also decreased significantly: colleges, colleges, and 
colleges - up to 8 (compared to 26 in 2013); universities of academies, institutes - up to four (against 8 in 2014) (Luhansk Regional State Administration, 2019).

The system of providing highly specialized medical care to the population in the region has practically ceased to exist. In the temporarily occupied territory, there are 11 cities of regional importance from14, including the regional center - Luhansk city, which housed almost all regional medical establishments equipped with modern medical equipment that provided such assistance to the population. Medical institutions that have moved to the territory controlled by the Ukrainian authorities are in leased premises and are not fully equipped with medical equipment. As of 01.01.2019, there are 17 Primary Health Care Centers (primary level), 4 city hospitals, 14 central district hospitals and dermatovenerologic dispensary (secondary level), 6 regional hospitals and 6 regional dispensaries (third level) and Regional Centers for Disaster Medicine, 3 city ambulance stations. There is a significant shortage of medical personnel in the region, staffing of $60.8 \%$ of staff positions, and of junior medical professionals with medical education $-79.8 \%$. The share of medical-equipped outpatient clinics is only $8 \%$, with computer equipment equivalent to $92.3 \%$, and at the secondary level, only $10 \%$ of the need (Luhansk Regional State Administration, 2019).

After a sharp decrease in the number of cultural institutions since 2014 (more than 50\%) and the number of cultural services by several times, in recent years there has been a positive dynamics of such services growth due to the relocation of regional cultural institutions to the territory controlled by the Ukrainian authorities and full restoration of their work. The enrollment of children in arts education in the region is almost $11.5 \%$ of the total number of students in secondary schools and compared to other regions it is quite high (in Kharkiv $8.24 \%$, Donetsk - 6.7\%, Dnipropetrovsk - 8.4\%, Mykolaiv $-7.3 \%$, Lviv - 4.5\%). Unfortunately, this is not the case with the network of regional sports facilities, which was almost lost.

\subsection{The current state of the ecological sphere of the region}

The ecological sphere of Luhansk region development is in a very difficult state. As a result of the armed conflict, significant pollution of the environment by chemical toxic substances, fragments of metals and heavy metals was created, numerous funnels were formed, which damaged the land and destroyed protected areas. An extremely dangerous situation is in the forestry of the region, which has suffered losses of about UAH 160 million, because of shelling. The loss due to the temporary occupation of most large industrial sites territory - major environmental pollutants, creates the basis for possible catastrophic consequences for the ecosystem.
There is a significant risk of water inflow to mines that are hydrologically linked to submerged mines in uncontrolled land, which can lead to flooding of large areas, displacement of the earth's surface, discharge of highly mineralized contaminated mine water to surface reservoirs and uncontrolled emissions. It also raises concerns about the lack of control over environmental compliance at industrial sites in the uncontrolled territories for air, water and subsoil pollution. Due to the general economic downturn, payments to the environmental protection fund from local budgets and payments of enterprises are decreasing, which complicates the implementation of environmental measures in the territory controlled by the Ukrainian government. These and other problems led to a decrease in the environmental quality of the area.

Primarily it concerns surface and groundwater pollution. According to the Ministry of Healthcare of Ukraine, according to the sanitary-chemical indicators, $35.7 \%$ of drinking water samples from the water supply systems of the centralized economic and drinking water supply do not meet the requirements of sanitary rules, the deviation of water quality by such indicators is $76.1 \%$. The main causes of large volumes of polluted water discharged into water bodies are the lack of capacity and the technical deterioration of many wastewater treatment plants, the discharge into the sewage network of industrial wastewater with a high content of petroleum products, heavy metals, etc. In addition, the environmental situation in the region is exacerbated by the significant accumulation of household and industrial wastes that cause significant environmental pollution and pose a real threat to environmental safety and public health.

During 2018, 557.5 thousand tons of waste was generated in the controlled part of Luhansk region, which is $13.4 \%$ less than in 2017, including the high-hazard class - 0.077 thousand tons $(44.9 \%$ less). By end of year 2018, 64.8 million tons of waste have been collected in designated areas or sites, which require appropriate treatment. An acute environmental problem remains the presence of pesticides and toxic chemicals, unsuitable or prohibited for use, amounting to 36.5 tons. The disposal of such wastes is a difficult problem, since there are no effective technologies for the destruction or processing of pesticides and their containers in Ukraine (Department of Ecology and Natural Resources of the Luhansk Regional State Administration, 2019).

Thus, the new (somewhat forced) configuration of material, natural and human resources, formed in the region and briefly described in this study, is the basis for structural transformation of the regional economy and reformatting of social space, transition to an inclusive development model, generation of new growth points and opportunities for further cooperation. To realize these potential opportuni- 
Table 2. Indicators of financial capacity of ATC of Luhansk region, calculated by the authors according to (Luhansk Regional State Administration, 2019; Decentralization power in Ukraine, 2017, 2018, 2019a)

\begin{tabular}{|c|c|c|c|c|c|c|c|c|}
\hline \multirow[b]{2}{*}{ Year } & \multicolumn{8}{|c|}{ Amalgamated territorial communities } \\
\hline & $\begin{array}{l}\text { Belokura- } \\
\text { kinska }\end{array}$ & $\begin{array}{c}\text { Novo- } \\
\text { pskovska }\end{array}$ & $\begin{array}{c}\text { Chmyriv- } \\
\text { ska }\end{array}$ & Troizka & $\begin{array}{c}\text { Belovod- } \\
\text { ska }\end{array}$ & $\begin{array}{l}\text { Krasnore- } \\
\text { chenska }\end{array}$ & Privilska & $\begin{array}{c}\text { Nizhno- } \\
\text { duvanska }\end{array}$ \\
\hline \multicolumn{9}{|c|}{ Area of ATC, $\mathrm{km}^{2}$} \\
\hline 2018 & 789,5 & 178,3 & 206,2 & 951,6 & 1597,0 & 244,7 & 221,9 & 226,7 \\
\hline \multicolumn{9}{|c|}{ Population, thousand people } \\
\hline 2018 & 13,2 & 12,2 & 6,7 & 14,6 & 23,2 & 6,7 & 1,4 & 3,2 \\
\hline \multicolumn{9}{|c|}{ Own income per inhabitant, UAH } \\
\hline 2016 & 2523,0 & 2115,0 & - & - & - & - & - & - \\
\hline 2017 & 3500,2 & 2927,9 & 1881,6 & - & - & - & - & - \\
\hline 2018 & 4225,7 & 3511,5 & 2234 & 4750,2 & 3517,8 & 1850,2 & 5926,2 & 3474,9 \\
\hline \multicolumn{9}{|c|}{ Budget subsidy level, $\%$} \\
\hline 2016 & 1 & 0 & - & - & - & - & - & - \\
\hline 2017 & 0 & $-0,9$ & 13,7 & - & - & - & - & - \\
\hline 2018 & 9,8 & 6,3 & 31,8 & 0 & 38,8 & 29,1 & $-7,1$ & 2,5 \\
\hline \multicolumn{9}{|c|}{ Share of expenditures for maintenance of management apparatus in financial resources of ATG, $\%$} \\
\hline 2016 & 15 & 10 & - & - & - & - & - & - \\
\hline 2017 & 23,7 & 15,1 & 28,5 & - & - & - & - & - \\
\hline 2018 & 24,4 & 18,8 & 51,7 & 18,2 & 34,5 & 33,7 & 33,7 & 29,5 \\
\hline \multicolumn{9}{|c|}{ Capital expenditures per capita, UAH. } \\
\hline 2016 & 1478 & 816 & - & - & - & - & - & - \\
\hline 2017 & 3586,5 & 1852,9 & 1515,3 & - & - & - & - & - \\
\hline 2018 & 1181,9 & 1150,4 & 1402,7 & 1122,4 & 2425,5 & 265,2 & 1768,2 & 894,8 \\
\hline \multicolumn{9}{|c|}{ Availability of the Development Strategy and the Plan for its Implementation (Social and Economic Development Plan) } \\
\hline 2019 & $+/+$ & $+/+$ & $+/+$ & $+/+$ & $+/+$ & $+/+$ & $-/+$ & developing \\
\hline
\end{tabular}

ties, the leadership and public of Luhansk region must find their unique qualities that distinguish this region from many others, and present them to the public in order to make appropriate adjustments to the Strategy of socio-economic development in the region. The process of local identification, whose activation is significantly facilitated by the decentralization reform, can help. It opens up considerable prospects for ensuring the ability of local governments to solve their own life issues and to be responsible for decisions made.

\subsection{Development of amalgamated territorial com- munities of Luhansk region}

During the decentralization in region, the number of amalgamated territorial communities is increasing - from two that were created in 2015 up to 24 in September 2019. In 2016 the first newly formed communities did not yet have a significant impact and their share in the region's own budget revenues was only $2.7 \%$. In 2018 , it increased to almost $10 \%$ or UAH 296 million, which allows them to solve the problem independently socio-economic problems of the territories and allows the implementation of significant projects on terms of co-financing under regional, national and international programs. Eight wealthy communities of region, which operated for more than one year, demonstrated quite different budgeting opportunities: from the largest Belovodsk ATC, which formed $2.8 \%$ of the region's own budget revenues, to the smallest in Novopskov ATC $(1.4 \%)$ and the population of Privilska ATC (0.3\%) (Luhansk Regional State Administration, 2019). The capacity of communities is measured by many factors and parameters, but the fundamental components are the degree of the ATC budget completeness (the amount of revenues received in the respective territory and the amount of funds provided by the central government for the exercise of delegated powers) and the efficiency of its spending by local authorities (Table 2).

In 2018, the average income per capita in the amalgamated communities of region increased by $88.4 \%$ to UAH 1 954.5. Moreover, for three ATC that were formed in 2015-2016 (Belokurakinska, Novopskovska and Chmyrivska), this indicator is better than the ones formed in 2017 (2308.9 UAH against 1786.3 UAH), but it grew at a much lower rate - only $18.9 \%$ against 2.9 times. It should be noted the smallest number of the Privilege community population has the highest budget per capita income. Most communities in the region receive a basic grant from the state budget, and only Novopskovska ATC in 2017 and Privilska ATC in 2018 transferred a reverse grant to the State budget. The most subsidized is Belovodska community, with the basic grant amounting to $38.8 \%$ of the total income. The breakdown of communities by budget is somewhat different. The average amount of capital expenditures per inhabitant (excluding own reve- 
nues of budgetary institutions) according to the ATC was UAH 1,276.4, only two communities (Belovodska and Privolska) spent on development more than the average of the region. At the same time, the share of expenditures on the maintenance of the community management apparatus in their financial resources is quite noticeable, especially in highly subsidized ATCs, such as Chmyrivska and Belovodska.

Notwithstanding the scarcity of own development resources but through the availability of long-term strategies and effective plans for implementation in almost all communities, and with the significant support of government infrastructure projects, amalgamated communities have been able to achieve signif-

icant success in building their future. In 2018 alone, they received UAH $37.6 \mathrm{mln}$. to strengthen the capacity of territorial communities and ensure the proper level of security and civil protection of the Luhansk community. A targeted subvention was used to develop project, town planning and planning documents; improving the quality of administrative services; creation of modern systems of community management organization; reconstruction, conversion, re-profiling of budgetary institutions buildings of amalgamated territorial communities; new construction, reconstruction, major overhaul of streets, roads, bridges, communal property crossings; purchase of vehicles for transportation of children to educational institutions, special purpose vehicles, etc. Today 354 projects are in the planning and implementation stages of the regions amalgamated communities (Luhansk Regional State Administration, 2019). This is gradually bearing fruit, reflected in the results of the ATC sustainable development, contributing to improving the comfort of life, primarily by approaching access to quality administrative, educational and medical services, overcoming environmental problems and addressing the harmonization of human and nature relations. Therefore, the basis is being created for the achievement of the most important directions of local self-government reform and the territorial organization of power in relation to human development, its well-being and security, and creation of a qualitatively new standard of living. In addition, this is not so much due to the legislative and financial basis of the state reform, but because of the role strengthening and real influence of the local leaders, the activation and cohesion of the community residents, the growing local business, which together with the local self-government bodies form a local identity.

\section{Quantification of sustainable development results of region}

The results of sustainable development of Luhansk region and its amalgamated communities have shown a rather difficult situation that has developed in the region at present, including through prolonged military conflict and the JFO to localize it. The most important critical indicators of socioeconomic status of region, both in rating and on the basis of a complementary analysis of development indicators, are determined: gross regional product per capita and disposable income per capita, industrial production index and volume of industrial output per capita construction works per capita and the amount of capital investment per capita, labour productivity and unemployment rate, number of entities in medium enterprises per 10 thousand people present population and the number of small businesses per 10 thousand people population, exports of goods per person. This list is based on the positions where the Luhansk region has been ranked lower among other regions of the country for four consecutive years, while a deeper analysis showed the lack or sufficiently low positive dynamics of them. Adding to this list are social security indicators for criminal offenses, health care and partially education, which are not fully or individually accounted for in the region, will get a group of outsourced development outcomes. Outsiders are not subjected to the quantification axis, because now no positive features of local uniqueness are formed but they must be taken into account in adversely affecting the sustainable development of the region.

In addition to the mentioned problems of sustainable development of Luhansk region, the analysis of its indicators also identifies the indicators that have a positive and in some cases stimulating effect on improving the standard of living in the region, contributing to the formation of its corresponding values and receptive uniqueness, creating a basis for territorial identity. They were applied to the axis of quantification of sustainable development results (Fig. 2).

Quantitative and qualitative transformation of data on the state of socio-economic development for 2018 and rating points made it possible to build on the strong features of region in the context of identifying the main features of attractiveness for its inhabitants, economic entities, investors, potential partners for cooperation, etc.

The composition of the best result group shows in what directions the feeling of home for the residents of Luhansk region can be formed: doing it possible to make extensive use of alternative energy sources and rational use of natural resources in the context of environmental protection. Due to the decentralization reform and its new perspectives on addressing the urgent issues of comfortable living, the ATC's are actively implementing energy-efficient measures: insulating the facades and roofs of schools and kindergartens, replacing doors and windows for energy-saving ones, installing heating systems for alternative uses. Not only does it reduce 


\begin{tabular}{|c|c|c|c|}
\hline Indexes & $\begin{array}{r}\text { Quantitative } \\
\text { result }\end{array}$ & Rating & Quantification \\
\hline \multirow{2}{*}{$\begin{array}{l}\text { Construction Cost Index, } \% \\
\text { The share of total capacity of boiler houses on alternative fuels in the }\end{array}$} & 87,1 & 23 & \multirow{4}{*}{ 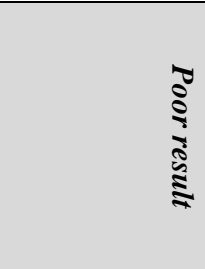 } \\
\hline & 1,2 & 23 & \\
\hline $\begin{array}{r}\text { An emission volumes pollution from stationary sources by } 1 \text { billion, } \\
\text { UAH GDP }\end{array}$ & 2,48 & 23 & \\
\hline $\begin{array}{r}\text { The share of apartment houses furnishing with housekeeping heat } \\
\text { metering devices, } \%\end{array}$ & 24,8 & 23 & \\
\hline $\begin{array}{r}\text { The share of thermal energy produced in the region from alternative } \\
\text { fuels or renewable energy sources, } \%\end{array}$ & 2,2 & 22 & \multirow{3}{*}{ 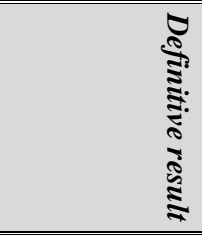 } \\
\hline $\begin{array}{l}\text { The share of wastes disposed of designated areas or sites or inciner- } \\
\text { ated (without energy) in the total amount of waste generated, } \%\end{array}$ & 88,3 & 22 & \\
\hline $\begin{array}{r}\text { The share of innovative products sales in the total volume of industri- } \\
\text { al products }\end{array}$ & 0,1 & $22-24$ & \\
\hline $\begin{array}{r}\text { Freight turnover of road and rail transport, thousand tons-kilometers } \\
\text { per } 1000 \text { population }\end{array}$ & 1489,4 & 21 & \multirow{3}{*}{$\begin{array}{l}\varpi \\
\vdots \\
\vdots \\
\vdots \\
\vdots\end{array}$} \\
\hline $\begin{array}{r}\text { The revenues of local budgets (without transfers) per person, thou- } \\
\text { sand UAH }\end{array}$ & 4,3 & 20 & \\
\hline \multirow{2}{*}{$\begin{array}{r}\text { Capital investment index, } \% \\
\text { The level of social services coverage of people in difficult circum- } \\
\text { stances, } \%\end{array}$} & 91,6 & 20 & \\
\hline & 94,7 & 19 & \multirow{4}{*}{ 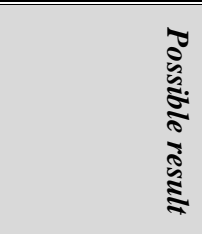 } \\
\hline Percentage of children enrolled in out-of-school education, $\%$ & 62,9 & 18 & \\
\hline \multirow{2}{*}{$\begin{array}{r}\text { The share of households with Internet access at home, \% } \\
\text { The share of settlements with separate collection of municipal solid } \\
\text { waste in the total number of settlements in the region, } \%\end{array}$} & 30,9 & 17 & \\
\hline & 1,3 & 17 & \\
\hline Agricultural production volume index, $\%$ & 103,5 & 16 & \multirow{4}{*}{$\begin{array}{l}\vdots \\
\vdots \\
\vdots \\
\vdots \\
\vdots \\
\vdots \\
\vdots\end{array}$} \\
\hline \multirow{2}{*}{$\begin{array}{r}\text { The foreign direct investment per capita, USD USA } \\
\text { The growth rate (decrease) of local budget revenues (excluding } \\
\text { transfers), } \%\end{array}$} & 202,7 & 15 & \\
\hline & 115,4 & 14 & \\
\hline \multirow{3}{*}{$\begin{array}{r}\text { Real wage index, } \% \\
\text { Employment rate of the population aged } 15-70 \text { years, } \% \\
\text { Percentage of rural children for transportation to and from home in } \\
\text { total pupils in need, } \%\end{array}$} & 111,9 & 14 & \\
\hline & $\begin{array}{l}56,9 \\
\end{array}$ & 13 & \multirow{5}{*}{ 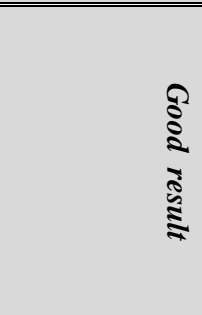 } \\
\hline & 99,7 & $12-13$ & \\
\hline \multirow{2}{*}{$\begin{array}{r}\text { Consumer Price Index, } \% \\
\text { Capital expenditures of local budgets (excluding transfers from the } \\
\text { state budget) per capita, thousand UAH }\end{array}$} & 109,3 & $10-13$ & \\
\hline & 1,3 & $10-12$ & \\
\hline $\begin{array}{r}\text { The share of sales volume of medium-sized enterprises in the total } \\
\text { volume, } \%\end{array}$ & 43,9 & 12 & \\
\hline $\begin{array}{l}\text { The share of comprehensive rural schools using the computers con- } \\
\text { nected to the Internet in the total number of such institutions, } \%\end{array}$ & 93,9 & 11 & \multirow{4}{*}{ 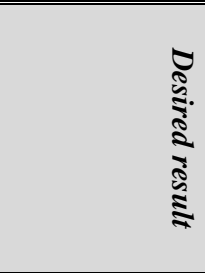 } \\
\hline $\begin{array}{r}\text { The share of small business entities (including microenterprises) in } \\
\text { total, } \%\end{array}$ & 37,8 & 11 & \\
\hline \multirow{2}{*}{$\begin{array}{r}\text { Rate of increase (decrease) of tax debt, } \% \\
\text { The rate of increase (decrease) in the volume of commissioned hous- } \\
\text { ing, } \%\end{array}$} & 113,3 & 8 & \\
\hline & 109,6 & 8 & \\
\hline $\begin{array}{r}\text { Volumes of fuel and energy resources consumed in the region during } \\
\text { the reporting period per capita }\end{array}$ & 0,73 & 4 & \multirow{4}{*}{ 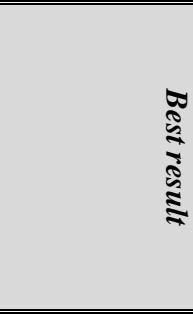 } \\
\hline $\begin{array}{l}\text { The level of implementation of energy-saving light sources in the } \\
\text { outdoor lighting of settlements, \% to the total number of light points }\end{array}$ & 66,8 & 3 & \\
\hline $\begin{array}{r}\text { The number of children in pre-school institutions per } 100 \text { places, } \\
\text { persons }\end{array}$ & 95 & 2 & \\
\hline $\begin{array}{r}\text { Growth rate (reduction) of pollutant emissions by stationary sources } \\
\text { of pollution per unit of population, } \%\end{array}$ & 62,7 & 1 & \\
\hline
\end{tabular}

Figure 2. The axis of sustainable development of quantification results of Lugansk region on 01.01.2019

energy consumption and save local budgets, it encourages local residents to save money and consume resources and improve community attractiveness.
Analyzing the content of indicators by the desired result indicates the priority development of small and medium-sized enterprises, which can provide an impetus for the development of region economy 
by opening new or expanding existing industries, generating new ideas and directions of business, improving public access to essential household services, providing creation new jobs and increased budget revenues. This concerns the amalgamated communities that are already actively developing local small businesses today.

For two years in a row, Novopskovska ATC is the winner of all-Ukrainian competition Best Practices of Local Self-Government, launched by the Ministry of Community and Territory Development in cooperation with the Council of Europe Program Decentralization and Local Government Reform in

Ukraine (Decentralization power in Ukraine, $2019 b$ ) in the nominations, regarding local economic development. «Slobozhans'kyy» agricultural cooperative is opened on its territory, which provides compatriots with work in plant and animal husbandry, first of all young people, pays all the proper taxes to the local budget, helps the school, takes care of landscaping.

The groups good result and average result give grounds to consider already a good tradition of de-

veloping the infrastructure of region, which was not particularly successful before the war, and was significantly lost or destroyed during the hostilities. Increasing employment, wages in the region, lower inflation, attracting foreign investment, increasing local budgets and their capital expenditures, including the care of preschool and preschool children and their leisure, are the values that build the right local traditions. The same is true of eventual results, the composition of which indicates the potential for the development of a predominantly social sphere, the development of which is complicated by circumstances close to military conflict.

The top three groups on the quantification axis poor, definitive and unsatisfactory results - have included sufficiently negative gains in the area, but with positive dynamics in recent years, allowing them to be grouped as possible points of growth in the near future. They are dominated by the environmental component, which is the most critical in the region for the mass of objective reasons and for the inaction of local governments. It is precisely the localization of potential dangers in this direction that should be addressed by strategic actions of both local communities and the whole region.

\section{Conclusions}

The Luhansk region has always been a unique industrial area with a rich history and essential for the development of natural, human and cultural resources. Unfortunately, the prolonged military conflict and the Joint Forces Operation to locate it have not only led to significant complications in the region's livelihoods, but have also led to the elimi- nation of all its values and the benefits that have shaped its identity. The analysis of sustainable development confirmed not only the presence but also the considerable accumulation of problems in the economic, social and environmental spheres. The last four years in a row in the rating of socioeconomic development of the regions of Ukraine confirmed the current unofficial positioning of Luhansk region only as an area in the conflict zone. It was determined that the loss of a large part of industrial potential and transport infrastructure due to temporary occupation, breaking of economic ties and termination of goods movement through the line of demarcation destroyed the industrial potential of region, caused the halt of many production and coal mining enterprises, caused the decline of other industrial production, industries. Most macroeconomic indicators show negative trends, and the financial, social and environmental spheres are in a state of fragmentary stagnation, which continues to diminish the image of the region, diminish its investment attractiveness, and scare away potential economic partners.

The positive trends are noted in the areas of implementation and consequences of decentralization reform in the region. Luhansk region is in the top half of the nationwide rating of regions in terms of forming able communities. Amalgamated communities have shown significant success in creating a comfortable environment for local residents, increasing their own income and capital investment, implementing new infrastructure projects, enhancing social cohesion and capacity. This has been proven possible through the development and effective implementation of socio-economic development strategies with government support and international donor assistance. This creates the basis for achieving the most important areas of reform in human development, well-being and security, creating a new standard of living and forming a local identity.

In order to determine the unique characteristics of region as a whole, the complementary analysis of its sustainable development indicators was quantified in the context of obtaining summary estimates of the area's strengths. The proposed quantitative and qualitative transformation of multiplicities data (sampling of socio-economic development indicators and rating points) made it possible to isolate and calibrate the territorial features of Luhansk region, which were plotted on the axis of sustainable development quantification results. Such a visualized interpretation of use result of the author's methodology for identifying a region greatly simplifies the process of identifying the advantages and values of a region in order to properly position it and build an effective socio-economic development strategy. Clear definition and conceptual framework, such a methodology can be used by the scientists and practitioners - representatives of national 
regional and local governments. In order to better understand the territorial identity and its importance, and serve as a basis for further identification of integrated territorial communities, which are currently limited in the absence of an array of data on their development through the short-term functioning of the ATC.

\section{References}

1. AQUINO K., REED A., THAU S., FREEMAN D., 2007, A Grotesque and Dark Beauty: How Moral Identity and Mechanisms of Moral Disengagement Influence Cognitive and Emotional Reactions to War, in: Journal of Experimental Social Psychology, 43, p. 385-392.

2. BERNARDO F., ALMEIDA J., MARTINS C., 2016, Urban identity and tourism: different looks, one single place, in: Proceedings of the Institution of Civil Engineers-urban Design and Planning, 170(5), p. 205-216.

3. BURKE P. J., 1991, Identity Processes and Social Stress, in: American Sociological Review, 56, p. 836-849.

4. BURKE P. J., STETS J. E., 2009, Identity Change, in: Identity Theory, eds Burke P. J., Stets J. E., Oxford University Press, New York, p. 175-196.

5. CARTER M. J., 2013, Advancing Identity Theory: Examining the Relationship between Activated Identities and Behavior in Different Social Contexts, in: Social Psychology Quarterly, 76(3), p. 203-223.

6. CSURGÓ B., SZATMÁRI A., 2019, Vidéki kultúra, helyi közösség és lokális identitás A kulturális örökség szerepe a lokális identitásépítésben és a közösségfejlesztésben Hajdúdorogon és Hajdúhadházon, in: Metszetek, 8(2).

7. DECENTRALIZATION POWER IN UKRAINE, 2017, Local Budget Revenue for 2016, https:// decentralization.gov.ua/uploads/attachment/document /23/\%D0\%92\%D0\%B8\%D0\%BA\%D0\%BE\%D0\% BD\%D0\%B0\%D0\%BD\%D0\%BD\%D1\%8F_\%D0 $\% \mathrm{~B} 4 \% \mathrm{D} 0 \% \mathrm{BE} \% \mathrm{D} 1 \% 85 \% \mathrm{D} 0 \% \mathrm{BE} \% \mathrm{D} 0 \% \mathrm{~B} 4{ }_{-} \% \mathrm{D} 0$ $\% \mathrm{~B} 2 \_\% \mathrm{D} 0 \% \mathrm{BC}$ \% $11 \% 81 \% \mathrm{D} 1 \% 86 \_\% \mathrm{D} 0 \% \mathrm{~B} 1 \%$ D1\%8E\%D0\%B4\%D0\%B6\%D0\%B5\%D1\%82_\% D0\%B2_\%D0\%B7\%D0\%B0_2016.pdf (04.09.2019).

8. DECENTRALIZATION POWER IN UKRAINE, 2018, Evaluation of the financial viability of 366 ATC's for 2017 by regions, https:// decentralization.gov.ua/uploads/library/file/183/366.pdf (04.09.2019).

9. DECENTRALIZATION POWER IN UKRAINE, 2019a, Luhansk Region, https://storage.decentraliza tion.gov.ua/uploads/attachment/document/361/\% D0\%9B\%D0\%A3\%D0\%93\%D0\%90\%D0\%9D\%D 0\%A1_\%D0\%9A\%D0\%90_\%D0\%9E\%D0\%91\% D0\%9B \%D0\%90\%D0\%A1\%D0\%A2_.pdf (04.09.2019).

10. DECENTRALIZATION POWER IN UKRAINE, 2019b, Competition that is agemate of decentralisation. Over 170 best local self-government practices presented to Ukraine, https:// decentralization.gov. ua/en/news/11934 (14.11.2019).

11. DEFFNER A., METAXAS T., 2007, Place marketing, local identity, and cultural planning: The
CultMark INTERREG IIIc project, in: DPRD Discussion Paper Series, 13(16), p. 367-380.

12. DEPARTMENT OF ECOLOGY AND NATURAL RESOURCES OF THE LUHANSK REGIONAL STATE ADMINISTRATION, 2019, Regional Report of the environment state in the Luhansk Region in 2018, http://www.eco-lugansk.gov.ua/images/ docs/Dopovid_pro_stan_navkolushnogo_prurod_ seredov/Regionalna_dopovid_2018.pdf (10.10.2019).

13. FELSON R. B., 1985, Reflected Appraisal and the Development of Self, in: Social Psychology Quarterly, 48, p. 71-78.

14. GERENCSÉR I., 2019, The role of individual responsibility in territorial development, in: Economic and Social Changes: Facts, Trends, Forecast, 12(4), p. 220-233.

15. HOGG M. A., ABRAMS D., 1988, Social Identifications: A Social Psychology of Intergroup Relations and Group Processes, Routledge, London.

16. KORZHOV H., 2010, Territorial identities: conceptual interpretations in modern foreign sociological thought, in: Sociology: Theory, Methods and Marketing, 1, p. 107-124.

17. LUHANSK REGIONAL STATE ADMINISTRATION, 2019, Implementation Results of the socioeconomic development program, http://loga.gov.ua/ oda/about/depart/economy/se_state/result (22.11.2019).

18. MINISTRY FOR COMMUNITIES AND TERRITORIES DEVELOPMENT OF UKRAINE, 2019, Regional Ranking Assessment for 2018, http://www.minregion.gov.ua/wp-content/uploads/ 2019/05/Reytingova-otsinka-za-2018-rikprezentatsiyni-materiali.pdf (05.11.2019).

19. MINISTRY FOR REGIONAL DEVELOPMENT, CONSTRUCTION, HOUSING AND COMMUNAL SERVICES OF UKRAINE, 2018, Rating score regions by 2017, http://www.minregion. gov.ua/wp-content/uploads/2018/05/Reytingovaotsinka-za-2017-rik-prezentatsiyni-materiali.pdf (05.11.2019).

20. MINISTRY FOR REGIONAL DEVELOPMENT, CONSTRUCTION, HOUSING AND COMMUNAL SERVICES OF UKRAINE, 2017, Rating score regions by 2016, http:// www.minregion.gov. ua/wp-content/uploads/2017/05/Reytingovaotsinka-za-2016-rik-prezentatsiyni-materiali.pdf (05.11.2019).

21. MINISTRY FOR REGIONAL DEVELOPMENT, CONSTRUCTION, HOUSING AND COMMUNAL SERVICES OF UKRAINE, 2016, Rating score regions by 2015, http://www.minregion.gov. ua/wp-content/uploads/2016/03/Otsinka-sotsialnoekonomichnogo-rozvitku-regioniv-za-2015-r.prezentatsiyni-materiali2.pdf (05.11.2019).

22. MURDOCH J., 2000, Networks - a new paradigm of rural development? in: Journal Of Rural Studies, 16(4), p. 407-419.

23. NAHORNA L.P., 2008, Regional identity: the Ukrainian context, Kuras Institute of Political and Ethnic Studies of the National Academy of Sciences of Ukraine.

24. OKTAY D., 2002, The quest for urban identity in the changing context of the city: Northern Cyprus. in: Cities, 19, p. 261-271. 
25. SABATIER P.A., JENKINS-SMITH H.C., 1993, Policy Change and Learning: An Advocacy Colation Approach, Westview Press, Boulder, Colorado, p. 4-33.

26. SHAO Y., LANGE E., THWAITES K., 2017, Defining Local Identity, in: Landscape Architecture Frontiers, 5(2), p. 24-41.

27. SEMENENKO I., HALHASH R., SIERIEBRIAK K., 2019, Sustainable development of regions in Ukraine: before and after the beginning of the conflict. in: Equilibrium. Quarterly Journal of Economics and Economic Policy, 14(2), p. 317-339.

28. STETS J. E., 2006, Identity Theory, in: Contemporary Social Psychological Theories, edited by Burke P., J. Palo Alto, Stanford University Press, CA, p. 88-110.

29. STRYKER S., [1980] 2002, Symbolic Interactionism: A Social Structural Version, Caldwell, Blackburn Press, NJ.

30. PRITCHARD A., MORGAN N. J., 2001, Culture, identity and tourism representation: marketing Cymru or Wales?, in: Tourism Management, 22, p. 167-179.

31. RASZKOWSKI A., 2014, Towards local development based on territorial identity, in: Regional Economy and Policy. Territories and Cities, Jan Evangelista Purkyně University in Ústí nad Labem, p. 32-37.

32. RAZUMKOV CENTRE, 2019, The Donbass War: The Realities and Prospects of Settlement (working version of the analytical report), http:// razumkov.org.ua/uploads/article/2019_Donbas.pdf. (22.10.2019).

33. STATE STATISTICS SERVICE OF UKRAINE, 2019, Regional Statistics, http://www.ukrstat.gov. ua/ (05.11.2019).
34. STATISTICAL PUBLICATION REGIONS OF UKRAINE 2018, 2018, ed. by Verne I., Part I, State Statistics Service of Ukraine, Kyiv.

35. STETS J. E., BURKE P. J., 2005, Identity Verification, Control, and Aggression in Marriage, in: Social Psychology Quarterly, 68, p. 160-178.

36. STETS J. E., CARTER M. J., 2006, The Moral Identity: A Principle Level Identity, in Purpose, Meaning, and Action: Control Systems Theories in Sociology, eds McClelland K., Fararo T. J., Palgrave MacMillan, New York, p. 293-316.

37. STETS J. E., CARTER, M. J., 2011, The Moral Self: Applying Identity Theory, in: Social Psychology Quarterly, 74, p. 192-215.

38. STRYKER S., 1980, Symbolic Interactionism: A Social Structural Version, Menlo Park, Benjamin Cummings.

39. UKRINFORM, 2019, Speech by the President of Ukraine at the debate of the UN General Assembly: The situation in the temporarily occupied territories of Ukraine, https://www.ukrinform.ua/rubricworld/2644704-porosenko-genasamblei-oon-rosiane-demonstrue-zodnogo-namiru-zupinitisa.html (20.02.2019).

40. UNDP UKRAINE, 2018, Peacebuilding Assessment: An Analysis of the Impact of the Crisis and Needs in Eastern Ukraine. Part I: Summary report, https://www.ua.undp.org/content/ukraine /uk/ home/library/poverty/Recovery_and_Peacebuilding _Assessment_ukr_vol1.html, (20.02.2019).

41. USTYMENKO V.A., ZABLODSKA I.V., BURBELO S.O., ZABLODSKA D.V., SAENKO P.O., 2019, Identification and Positioning of the United Territorial Municipalities: Methodical Tools, in: Economics and Law, 1(52), p. 44-50. 